\title{
Arbor
}

\section{La escultura policromada. Criterios de intervención y técnicas de estudio}

\section{Rosaura García Ramos, Emilio Ruiz de Arcaute Martínez}

Arbor CLXIX, 667-668 (Julio-Agosto 2001), 645-676 pp.

\section{Introducción}

Aunque hoy se está poniendo el acento en la restauración del Patrimonio Cultural que incluye la escultura policromada, en muchos casos estas intervenciones son excesivamente agresivas y olvidan dos cuestiones primordiales como son la importancia de la conservación preventiva y del estudio científico de la obra. Un estudio que ha de ser multidisciplinar y aún mejor interdisciplinar.

En especial, en el caso de los retablos de grandes dimensiones que se encuentran ubicados en diferentes municipios de la península, la única oportunidad para la realización de un serio y completo estudio es el momento en que se lleva a cabo una intervención de conservación-restauración. Y por ello no se debe dejar pasar esta oportunidad.

Un estudio científico preliminar posibilita una mejor diagnosis de los problemas, la realización de un proyecto de intervención más coherente y la obtención de una inapreciable información técnica, con utilidad para la conservación de la obra, pero también para la Historia de Arte, que de otro modo sería imposible obtener.

Como es sabido, una de las aportaciones del arte español es la creación a partir de finales del siglo XV de los grandes retablos de talla en madera, entre los que destacan los de las catedrales de Sevilla, Toledo, Oviedo, etc., y que se generalizan y desarrollan en especial hasta finales del Barroco con una influencia que se deja sentir también en los territorios de ultramar. 
Este tipo de grandes complejos arquitectónicos y escultóricos presenta básicamente una diferencia de escala con otros retablos centroeuropeos o con la escultura aislada, per eso su estudio y conservación debe afrontarse con el mismo rigor metodológico que las piezas pequeñas.

El proyecto de intervención en cualquier caso, y especialmente en los retablos debe obedecer a ciertas reglas de economía:

- Se han de primar los aspectos de conservación preventiva. Es decir, la intervención debe centrarse por un lado en la solución de los problemas que generan el mal estado de conservación de la obra, como la presencia de humedades, ataques de insectos $\mathrm{u}$ hongos xilófagos, la incidencia de aves o roedores, los usos del objeto, las visitas, las oscilaciones de H.R. y temperatura, los sistemas de iluminación, las cuestiones de seguridad del edificio, etc. Cualquier intervención sobre un objeto cultural resultará baldía si no se solucionan adecuadamente estos aspectos.

- Se han de plantear en un segundo término los trabajos de conservación. Es decir, aquellos que afectan a la estabilidad estructural, la consolidación, limpieza, etc.

- Sólo en último lugar, y dependiendo de las posibilidades económicas, se pueden atender las cuestiones de restauración. En concreto, la intervención de reintegración sobre un retablo de grandes dimensiones suele seguir por lo general una escala diferente a un pequeño retablo o a una pieza aislada, dependiendo de la accesibilidad del público y de las distancias de observación.

La escultura policromada en España supone uno de los pilares fundamentales del patrimonio artístico. Tanto en tallas sueltas como en conjuntos retablísticos, contamos con una abundancia y calidad que no se corresponde con el interés tomado por los estudios.

Si bien se trata de expresiones muy enraizadas en la tradición cultural y popular, estas obras han sufrido un cierto abandono que sólo en los últimos años parece haber llamado la atención de aficionados y especialistas. Son muchos los pueblos que cuentan con magníficos retablos y esculturas que sin embargo se encuentran fuera de los circuitos culturales. Una labor de restauración podrá recuperar en cierta medida sus valores artísticos, pero sobre todo la puesta en valor tras un estudio adecuado y una correcta conservación que los integre dentro de redes de turismo cultural, posibilitará su adecuada permanencia.

Desde los inicios de la Historia de la Restauración de Obras de Arte y hasta bien entrado el siglo XX, se presta una especial atención a la restauración de pintura, considerándose la escultura un arte menor y siendo ésta objeto de intervenciones poco ortodoxas, en comparación 
con los criterios seguidos en ese mismo periodo de tiempo para la restauración de pinturas.

Esto ha supuesto la realización de auténticas barbaridades que han destruido gran parte de nuestro legado artístico. La mayor parte de estos atentados se han centrado en las policromías, pero con frecuencia también han afectado a la talla, al soporte.

Por eso hoy nos encontramos con la imperiosa necesidad de afrontar un correcto estudio de la escultura policromada, que permita conservar adecuadamente las piezas y conjuntos que aún existen, pero además obtener la información suficiente para el correcto conocimiento de la evolución de los usos y técnicas de la talla y de la policromía. Estudio muy complejo que está aún por desarrollar de forma global.

Existen, eso sí, intentos puntuales como el proyecto sobre Policromía Barroca en Europa dentro del programa Raphael, apoyado por la Comunidad Europea; los trabajos del Grupo Latino de Escultura Policromada, los de la sección de Escultura y Policromía del Comité de Conservación de ICOM o los de la Asociación Brasileña de Conservadores (ABRACOR).

En cualquier caso, conviene marcar las directrices, criterios y técnicas que hay que seguir para el correcto estudio de la escultura policromada, que ha de cubrir tanto los aspectos constructivos y técnicos de los soportes como de las policromías.

\section{Estudio de las policromías}

A mediados de este siglo, en Austria y Alemania, los técnicos en restauración de escultura comienzan a mostrar un destacado interés por el estudio de las policromías originales. Posteriormente se llevan a cabo las primeras restauraciones científicas en los talleres del IRPA (Instituto Real del Patrimonio Artístico) de Bruselas, cuando aún se encontraban en los sótanos de los Museos Reales de Arte e Historia de esa ciudad. Es en esta época, bajo la dirección de Agnès Ballestrem, cuando se comienzan a realizar los primeros exámenes de estratos polícromos, siguiendo un riguroso método arqueológico, basado en el estudio detallado de las capas que componen cada una de las policromías existentes.

Este estudio detallado de los componentes materiales revela el estado de conservación de los mismos, los deterioros que sufren y sus causas, las sucesivas intervenciones, los cambios y añadidos históricos que presenta la obra, los usos que de ella se han hecho, las técnicas de su 
fabricación o elaboración, incluso en algunos casos, su autenticidad o falsedad, ya sea ésta total o parcial.

Parte de este estudio se centra en el análisis y determinación de las capas de cada policromía, que da como resultado un gráfico con las correspondencias de las mismas, es decir su orden cronológico y la superficie que ocupan, ya que no todas las policromas superpuestas, o repolicromías, son generales, a veces sólo se repolicromaban algunas partes de la imagen.

Este examen es de gran importancia e incide de manera muy especial en la elaboración de la Historia material de la obra y su conocimiento desde el punto de vista de la Historia del Arte.

Es fundamental no confundir repinte y repolicromía y, ante los abusos que en la práctica se han venido cometiendo, conviene reivindicar el valor histórico, artístico y documental de esta última.

Para el correcto conocimiento y relación de las policromías, se ha desarrollado una técnica que permite el estudio de su correspondencia, sin la necesidad de eliminar ninguna de ellas. Esta técnica está basada en los mismos principios que rigen el estudio de los estratos en las excavaciones arqueológicas.

Hoy los criterios deontológicos nos obligan a conocer antes de intervenir. Conocer las patologías, conocer las características de cada pieza y conocer las posibilidades e inconvenientes de cada tratamiento, encontrando una gran similitud entre la restauración y la medicina en las formas y los procedimientos.

Al igual que en esta disciplina, en nuestra profesión los estudios $\mathrm{y}$ análisis previos se han hecho imprescindibles y los tratamientos son cada vez menos agresivos para el paciente. Por ello los métodos de examen tratan de ser cada vez menos drásticos, recurriendo en lo posible a técnicas de estudio no destructivo.

En concreto, a la hora de enfrentarse al tratamiento de una escultura policromada, es necesario conocer los materiales de que está compuesta, su estructura y número de piezas, las transformaciones que ha sufrido a lo largo de su historia, su estado de conservación, etc.

El hecho de que nos encontremos tan a menudo con esculturas que presentan varias policromías superpuestas se debe a que este tipo de piezas, en especial las imágenes de culto, ha sido objeto de numerosos cambios a través de los tiempos, ya fuese por los dictámenes de la moda o para mantenerlas en «buen uso». Es frecuente encontrarse piezas sueltas o conjuntos de ellas que, realizadas en un periodo concreto, fueron en otro momento transformadas, incorporándolas a nuevos retablos y que por lo general presentan nuevas policromías. 
Hasta hace poco, y aún hoy en día persiste este tipo de prácticas, se ha recurrido a metodologías de estudio y trabajo muy agresivas. Basta saber que es demasiado frecuente encontrase con piezas que han sido desmontadas, desmembradas o descompuestas radicalmente para conocer la estructura del soporte, para buscar información en su interior, etc. También este sistema de trabajo destructivo se ha practicado, y por desgracia se practica, a la hora de estudiar las policromías subyacentes, para lo que muchos se basan en la eliminación sistemática de las policromías superpuestas.

La ausencia de un examen preliminar detallado, absolutamente necesario, da lugar a numerosos atentados contra la obra como cuando se eliminan policromías superpuestas de forma inconsciente o se llevan a cabo reintegraciones que no se atienen a ningún nivel en concreto, por ignorar la correcta sucesión cronológica de policromías.

La falta de criterios éticos ha motivado que en muchas ocasiones se hayan considerado estas capas de policromías superpuestas como repintes. El no valorarlas como capas «originales» ha favorecido que hayan sido eliminadas sistemáticamente, sin tener en cuenta su valor histórico, artístico y documental. Estas eliminaciones se han realizado con frecuencia sin los medios necesarios y sin el auxilio de la técnica, por lo que nos encontramos a veces con policromías originales realmente masacradas.

En otras ocasiones, la falta de coherencia a la hora de eliminar determinadas policromías superpuestas ha tenido como consecuencia la creación de «falsos históricos», es decir piezas que muestran un conjunto de policromías parciales de distintas épocas y cuya apariencia no se corresponden con ningún periodo real de la historia de la obra.

Por otro lado, también se observa una mayor discriminación con respecto a ciertos periodos artísticos, ya sea por parte de historiadores o restauradores, como es el caso del Neoclásico o el Neogótico, lo que ha provocado que casi no queden policromías representativas de los mismos.

Estas actuaciones suelen tener una justificación más que dudosa. La falta de respeto por la integridad de la obra de arte y por sus aportaciones históricas y los prejuicios estilísticos han causado numerosas destrucciones de policromías, que constituyen una parte substancial de muchas obras. Por ello el Grupo Latino de Trabajo sobre Escultura Policromada estableció unas definiciones que tratan de poner en valor el carácter histórico y el interés artístico de las diferentes muestras de la evolución de una escultura. En estas definiciones se recogen los términos siguientes: 
Policromía: «Se entiende por policromía la capa o capas, con o sin preparación, realizada con distintas técnicas pictóricas y decorativas que recubre, total o parcialmente, esculturas o ciertos elementos arquitectónicos y ornamentales, con el fin de proporcionar a estos objetos un acabado o decoración. La policromía es consustancial a los mismos y forma parte de su concepción e imagen».

Repolicromía: "Debe ser considerada como una renovación, puesta al día o matización de los objetos, con intención de conferirles un nuevo uso o adaptarlos a los gustos de la época. Es una policromía, total o parcial, realizada en un momento histórico diferente al de la concepción del objeto policromado, cuya elaboración responde a las mismas características de los métodos y técnicas de la época a la que pertenece».

Repinte: «Se entiende por repinte toda intervención, total o parcial, realizada con la sola intención de disimular u ocultar daños existentes en la policromía, imitando o transformándola; normalmente no respeta los límites de la laguna y no suele tener intención de cambiar o actualizar la decoración del objeto».

Reintegración de policromía: «Se entiende por reintegración la técnica de restauración que permite, con métodos diversos, devolver a la policromía la unidad compositiva y cromática perdidas. Se cierne exclusivamente a los límites de la laguna y se realiza con materiales inocuos, reversibles y diferentes de la policromía que quiere reparar y bajo ninguna circunstancia deberá crear un falso histórico».

Conclusiones: «En consecuencia con estas definiciones hay que considerar la repolicromía como un elemento, en principio, a conservar, ya que debe ser entendida como una manifestación original de la época en la que fue realizada $y$, por tanto, es consustancial a la evolución histórica de la escultura».

Como vemos, la repolicromía debe ser considerada una policromía original de su época, perteneciente a un momento histórico determinado. Por ello ha de ser entendida como un elemento a conservar. La Ley 16/1985 de 25 de junio del Patrimonio Histórico Español, en su artículo 39.3, dice:

«Las restauraciones de los Bienes a que se refiere el presente artículo respetarán las aportaciones de todas las épocas existentes. La eliminación de alguna de ellas sólo se autorizará con carácter excepcional y siempre que los elementos que traten de suprimirse supongan una evidente degradación del Bien y su eliminación fuera necesaria para permitir una mejor interpretación histórica del mismo. Las partes suprimidas quedarán debidamente documentadas». 
El repinte, sin embargo, difiere de las características técnicas de la policromía que pretende reparar $\mathrm{y}$, como se ha dicho, ni respeta los límites de la laguna ni suele tener intención de cambiar o actualizar la decoración del objeto.

Desde esta perspectiva, más coherente y respetuosa con el patrimonio, se tiene que recurrir a métodos y técnicas en lo posible no destructivos, que nos permitan la obtención de datos suficientes sin tener para ello que destruir o eliminar información que puede ser muy valiosa en el futuro. No podemos aceptar, desde nuestro punto de vista y salvo excepciones muy evidentes, la destrucción de una serie de datos para obtener otros, ya que todos en principio deben gozar de la misma importancia.

\subsection{La técnica de correspondencia de policromías:}

En primer lugar conviene decir que el «estudio de correspondencia» no se debe llevar a cabo cuando no se dispone de los medios necesarios o se carece de la experiencia y conocimientos sobre esta técnica, ya que se podrían provocar daños irreparables o llegar a unas conclusiones erróneas que podrían alterar posteriores estudios sobre la obra.

También es conveniente juzgar hasta qué punto es necesario y adecuado llevar a cabo un estudio de estas características, sobre todo en aquellas piezas que, por su buen estado de conservación, no presenten deterioros como lagunas o craquelados que permitan la observación de los estratos. Hay que tener en cuenta también qué piezas se destinarán a este tipo de estudios, ya que el número de horas que se necesitan para su realización es sumamente elevado, de ahí que sea tan costosa su realización. En cualquier caso, es evidente que para llevarlo a cabo se ha de tener la certeza de que la obra tiene más que una policromía, es decir que existen policromías subyacentes.

El análisis de las policromías debe evitar al máximo las intervenciones destructivas, para ello se han de aprovechar las lagunas existentes, realizando "ventanas de estudio» sólo en caso de que sea absolutamente necesario. Éstas han de ser de un tamaño mínimo, tan sólo unos milímetros, y localizarlas en bordes de lagunas y en lugares determinantes pero suficientemente ocultos, para lo que es necesario contar con el equipamiento adecuado. 


\section{Objetivos:}

La información que se pretende obtener cubre dos objetivos básicos. En primer lugar conocer la evolución en el tiempo de la pieza, los usos que de ella se han hecho, su adaptación a los dictámenes de la moda, etc., llegando, si es posible, a reconstruir gráficamente cada policromía. Y en segundo lugar recoger la mayor cantidad de datos para el mejor conocimiento de la evolución de las técnicas de policromía a lo largo de la historia, de los motivos decorativos, etc.

A estos objetivos se llega mediante la determinación de:

- número de policromías,

- número de estratos de cada policromía,

- localización y extensión de cada una de ellas,

- técnica de ejecución de cada una de las mismas,

- tipo de decoraciones,

- características como textura, porosidad, etc.,

- estado de conservación,

- datación absoluta o relativa.

Esta información puede utilizarse a la hora de eliminar alguna de las policromías, pero éste no es el objetivo del estudio. La decisión de eliminar alguna de ellas es una cuestión de criterios específicos que se analizarán más adelante.

Aplicación de la técnica:

El proceso de trabajo consta de cinco fases sucesivas que se van complementando:

$1^{a}$ EXAMEN PRELIMINAR.

$2^{\text {a }}$ EXAMEN AL MICROSCOPIO.

$3^{\text {a }}$ ANÁLISIS DE LABORATORIO

$4^{\text {a }}$ ELABORACIÓN DE LA CARTA DE CORRESPONDENCIAS.

$5^{\mathrm{a}}$ RECONSTRUCCIÓN GRÁFICA DE LAS POLICROMÍAS.

Examen preliminar:

Esta primera fase consiste en la observación minuciosa y detallada de la obra. Se ha de revisar su superficie, la presencia de lagunas de interés, grietas, existencia de policromías subyacentes, etc. Es conveniente ya desde esta fase comenzar una documentación fotográfica detallada. 
Los resultados obtenidos determinarán la necesidad o no de continuar el estudio en sus diferentes fases, en función de la existencia de una o más policromías, de su localización y de su extensión.

Una vez que se ha decidido profundizar en el estudio, es necesario concretar con exactitud las zonas a examinar, evitando así las incursiones indiscriminadas por la geografía de la pieza.

Estos puntos han de estar situados en lugares estratégicos, como:

- zonas de intersección entre los distintos elementos decorativos de la talla (cabello-carnación, manto-túnica, manto-carnación, pie-peana, etc.).

- zonas de cambio (paso de un color a otro, de una superficie lisa a otra decorada, de una técnica a otra, etc.).

- bordes de determinadas lagunas.

La correcta elección de estas zonas reducirá al mínimo la realización de ventanas, favorecerá la exactitud de los resultados y tendrá una importante repercusión en la elaboración de la carta de correspondencias y en la reconstrucción de las policromías subyacentes.

Para ello se elegirán lugares poco visibles y siempre que sea posible en zonas profundas o protegidas, que son las que guardan el mayor número de capas por estar menos expuestas a los roces y agresiones.

Tras la observación minuciosa se habrá de realizar una serie de croquis donde se reflejen los lugares precisos a estudiar y que servirán de guía para el examen al microscopio. Los puntos elegidos se identificarán mediante una clave numérica y la descripción del mismo.

Con posterioridad es necesario llevar a cabo un examen completo de la policromía superficial, recogiendo el mayor número de datos posibles sobre sus características (porosidad, textura, número de estratos, técnica, etc.)

Este es el momento de determinar el estado de conservación de las policromías, lo que nos indicará la necesidad o no de realizar un tratamiento de fijación de las mismas, antes de pasar a la siguiente fase. Ya que si existen levantamientos, falta de adhesión entre estratos o de cohesión en los mismos no se podría trabajar sin riesgo sobre la pieza, realizando, por ejemplo, la limpieza de suciedad superficial o de cualquier resto de depósito ajeno a la policromía.

Examen al microscopio:

Siguiendo los puntos de observación preestablecidos en los croquis, se comienza el examen de cada uno de ellos. Éste ha de realizarse 
654

\section{Rosaura García Ramos, Emilio Ruiz de Arcaute Martínez}

Foto 1. Examen de una pieza de piedra policromada, procedente de la Catedral de Santa María de Vitoria, al microscopio binocula (Zeiss OPMI 1)

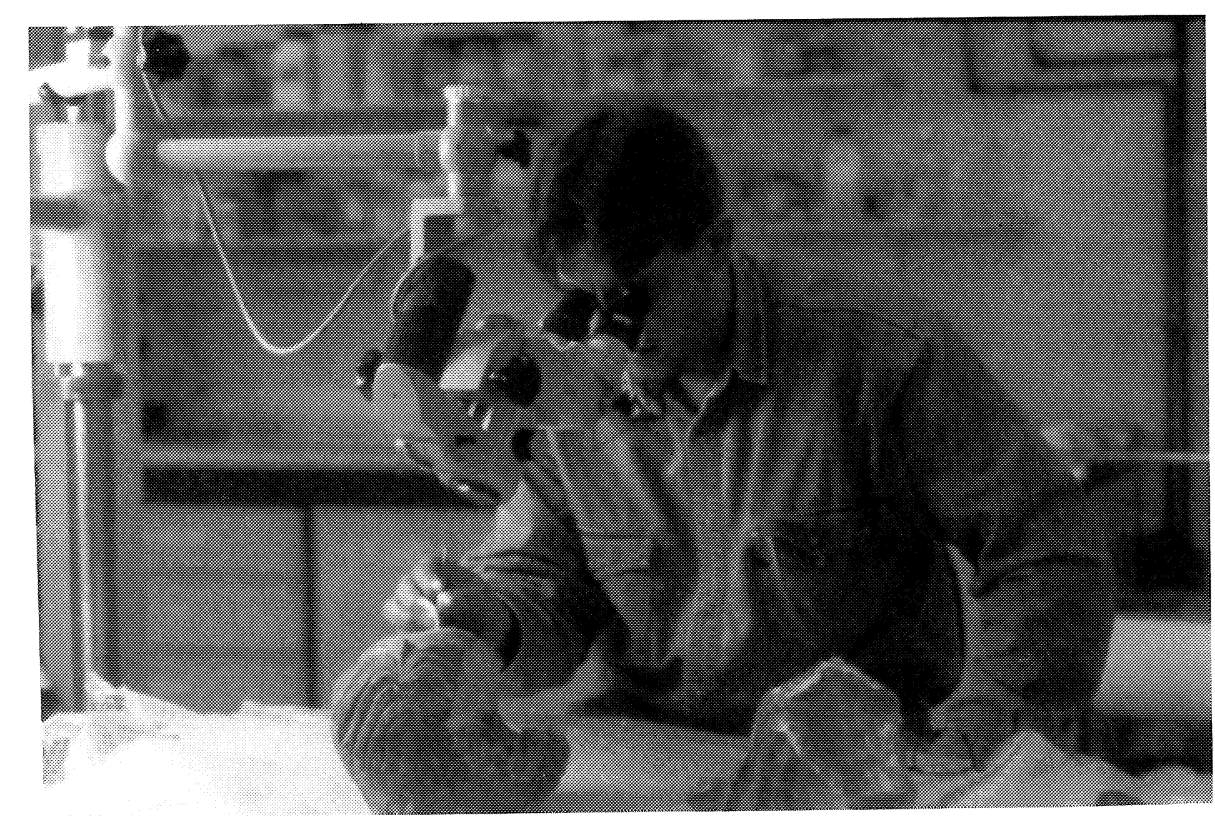

Foto 2. Examen de la Virgen de Caicedo-Yuso con video-microscopio (Keyence V-H 5901)

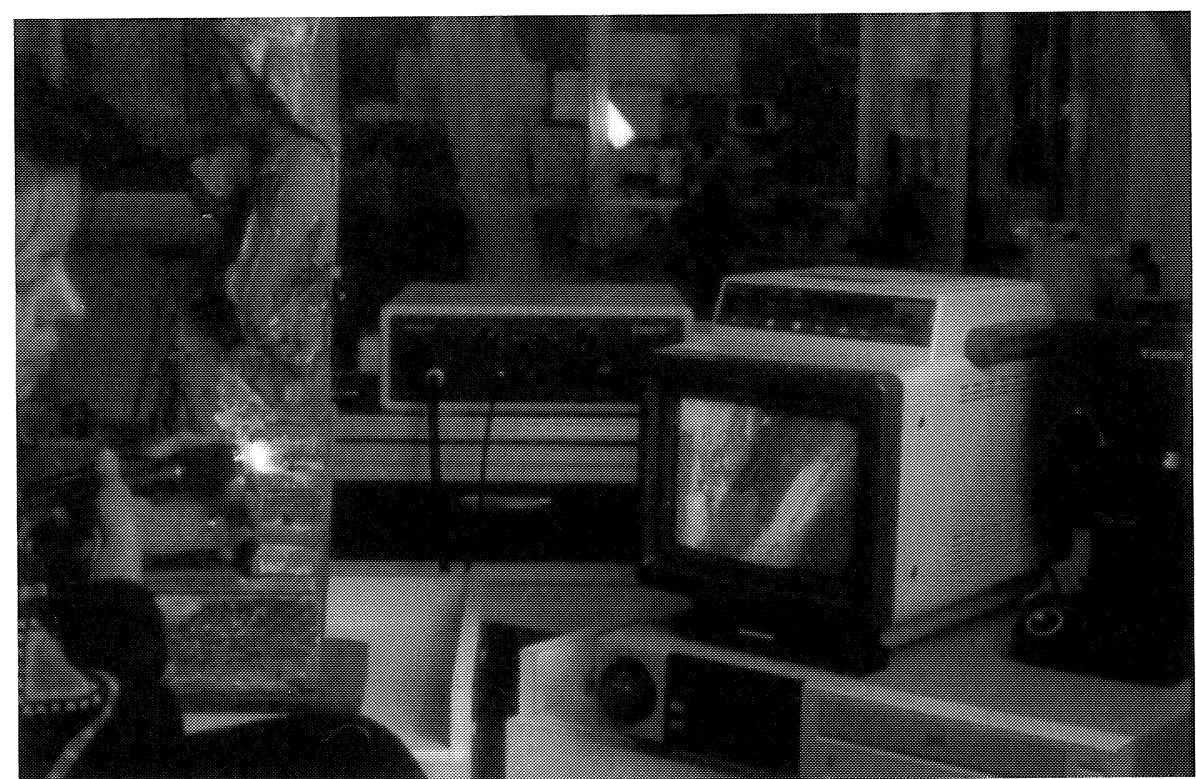


al microscopio binocular y, si se dispone de él, con la ayuda del vídeo-microscopio de exploración.

Estos aparatos permiten trabajar con unos aumentos que pueden oscilar entre $16 \mathrm{x}$ y $1000 \mathrm{x}$. Lo que posibilita la exhaustiva exploración de los diferentes estratos, incluso la más fina de las capas y las características de cada una de ellas (colas, capas de color, número de estratos de la preparación, texturas, brillo, transparencia, tipo de granos de los pigmentos, desgastes, etc.).

La posibilidad de contar con muchos aumentos en el vídeo-microscopio permitirá evitar parte de la toma de muestras para la realización de estratigrafías en el laboratorio, reduciendo los análisis destructivos al mínimo.

No obstante, hay que decir que presenta cierta dificultad para su manejo al estudiar una escultura. Sin embargo algunas ventajas de este equipo son la posibilidad de grabar las imágenes y la observación de éstas en un monitor, haciendo el trabajo menos fatigoso y permitiendo que la misma imagen pueda ser vista y analizada por varios técnicos a la vez.

A parte de estos aparatos, se necesita el siguiente material de trabajo:

- Bisturí de cuchilla recambiable, de un acero que permita el afilado de la hoja sin provocar rebabas que puedan dañar los estratos durante el trabajo. Son muy adecuados los utilizados en microcirugía y en cirugía de huesos, por la dureza, tamaño y durabilidad de las cuchillas.

- Acuarelas y pinceles, para realizar gráficamente y a color la estratigrafías de las diferentes policromías que se vayan examinando.

- Esencia de petróleo o, en su defecto, W. Spirit, para refrescar las zonas de estudio y poder ver con claridad las superficies de los distintos estratos.

- Bastoncillos de algodón, de madera, y pincel fino para limpiar las zonas en proceso de estudio.

- Realización de macro-fotografías.

- Toma de imágenes en vídeo, lo que permitirá el examen de los diferentes puntos por varios técnicos simultáneamente.

En primer lugar se procede a la observación y examen de las lagunas elegidas en los croquis anteriores, no obstante, si estos puntos no son suficientes para completar el estudio de las distintas policromías, es necesario comenzar con la abertura de las «ventanas» detalladas también en dichos croquis. 
Estas ventanas han de ser de tamaño mínimo, 3 × 7 o $10 \mathrm{~mm}$ aproximadamente, y deben también estar situadas en los lugares más estratégicos y menos visibles.

Se deben realizar con bisturí, con un mínimo de 50 aumentos, ya que con menos aumentos se corre el peligro de que algún estrato pase desapercibido, y deben abrirse dejando al descubierto cada uno de los estratos que forman las diferentes policromías, incluso aunque se trate de una fina capa de cola.

Durante la observación al microscopio, es necesario reflejar detalladamente por escrito los siguientes datos:

- Número de estratos y estado de conservación de cada uno de ellos.

- Existencia de veladuras superficiales, su estado de conservación, color, dureza, grosor, transparencia, etc.

- Color, tipo, tamaño y distribución de los diferentes granos de pigmentos.

- Presencia de elementos decorativos, tales como estrellas, brocados, brocados aplicados, estofados o cualquier otro elemento decorativo, etc.

- Preparación, número de capas que la componen, textura de cada una de ellas, color, presencia de capas intermedias de aislamiento y sus características.

- Telas de refuerzo o utilizadas como base para la preparación.

Todo ello debe reflejarse mediante gráficos, con el máximo de anotaciones posibles, de cada una de las zonas observadas. Dichos gráficos deben llevar la identificación del lugar examinado.

Es importante tener en cuenta que para realizar un estudio de este tipo, sin errores en las afirmaciones, es necesario que el restaurador posea la suficiente experiencia en este campo, como para que le permita establecer las semejanzas o diferencias de textura, grosor, dureza, porosidad, brillo, etc. de los estratos de los distintos puntos observados, independientemente del nivel que estos ocupen en cada una de las zonas. Esta labor es difícil, ya que en la mayor parte de los casos las piezas presentan repolicromías parciales a las que se superponen otras totales, o viceversa. Por ello se suele encontrar en unos lugares un número de policromías distinto al de otros y el restaurador deberá, en estos casos, relacionarlas adecuadamente.

En esta fase se pueden establecer ya algunas hipótesis sobre la datación relativa de cada una de las policromías.

Por otro lado, un técnico experimentado puede llegar a veces a identificar ciertas técnicas o pigmentos característicos de periodos concretos, lo que facilitará la datación absoluta. 
Análisis de laboratorio:

A veces, cuando hay dudas o los datos obtenidos del estudio anterior no son suficientes para determinar los materiales o las capas que componen una estratigrafía, es necesario recurrir a la toma de muestras para la realización de análisis propios del laboratorio (en este punto hay que señalar que en raras ocasiones, cuando hay muchas policromías, se consigue obtener una muestra con todos los estratos, ya que por lo general se suelen romper o separar al intentar tomarla).

Para ello también hay que determinar con exactitud las zonas de dónde han de tomarse dichas muestras, de manera que sean lo más útiles posible y no exista ningún problema para identificarlas posteriormente. Es evidente que aunque la toma de muestras para el análisis en laboratorio es necesaria no se debe llevar a cabo por el sólo hecho de satisfacer la curiosidad de cada uno. Al tratarse de un tipo de análisis destructivo, ha de estar debidamente justificado.

En estos casos es el restaurador el que mejor sabrá elegir los puntos de muestreo, dado que es el que ha llegado, tras las fases anteriores, a un mejor conocimiento de la geografía de la obra y podrá determinar de dónde se pueden extraer todas las capas deseadas, con el mínimo riesgo de exfoliación o rotura alguna.

Tras la preparación y observación al microscopio de las correspondientes estratigrafías y láminas delgadas y la realización de los análisis de laboratorio que sean necesarios (sencillos, como tinciones, o más complejos, como cromatografía, espectrometría infrarroja, difracción de rayos $\mathrm{X}$, etc.) se pueden obtener datos de gran interés, como:

- Aglutinantes empleados (oleosos, proteicos, etc.).

- Identificación exacta de los pigmentos.

- Identificación de las lacas y origen de las mismas (vegetal o animal).

- Tipo de carga utilizada en la preparación.

- Presencia de capas de aislamiento.

- Grosor en micras de cada uno de los estratos.

- Etc.

De los resultados de dichos análisis se debe elaborar la correspondiente documentación, es decir las fichas de descripción de las estratigrafías y macro-fotografías de las muestras con diferentes tipos de aumentos y de luz. 
Esta documentación se adjuntará al dossier del estudio que se está realizando de la obra.

Otras técnicas auxiliares:

En ocasiones y dependiendo de las características y el estado de las policromías se puede recurrir a técnicas físicas de estudio no destructivo, que nos pueden permitir obtener información sobre ciertos aspectos de las policromías.

Frecuentemente utilizamos la radiografía para localizar motivos decorativos subyacente como «brocados aplicados», estrellas u otros elementos realizados con láminas metálicas.

Foto 3. Nuestra Señora de Escolumbe. Localización y detalles radiográficos que muestran la presencia de restos de «brocados aplicados».

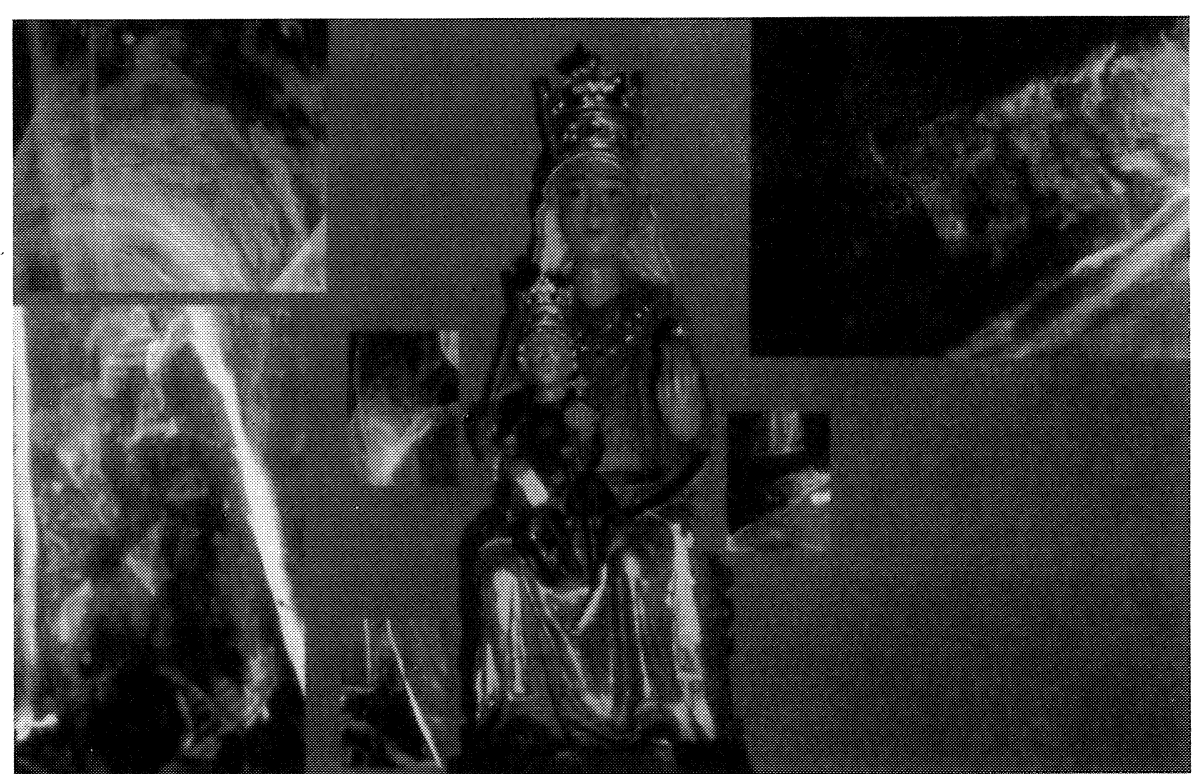

No hay que renunciar tampoco a la utilización de la Reflectografía de I.R., en especial cuando nos encontramos con policromías superficiales lisas y realizadas al óleo sin preparación. En estos casos podemos llegar a observar detalles subyacentes como el dibujo de las cejas, ojos o motivos decorativos realizados con colores oscuros.

También hemos obtenido resultados con equipos de estudio multiespectral en la banda de los ultravioletas para la apreciación de motivos muy degradados que no era posible localizar con luz natural. 
La escultura policromada. Criterios de intervención.......

Hay que tener en cuenta, no obstante, que estas técnicas no siempre son efectivas, ya que la acumulación de estratos, la rugosidad de las texturas o la dificultad de acceder a determinadas zonas en tallas con volúmenes muy complejos, dificulta su utilización.

Elaboración de la carta de correspondencias:

Para la elaboración de las conclusiones del estudio es necesario comparar todos los muestreos efectuados y a partir del resultado de estas comparaciones se construye la carta de correspondencias.

La carta tiene una estructura de trama a partir de dos ejes. En el superior se reflejan los puntos estudiados y en el izquierdo la distribución por niveles de las policromías examinadas.

Cada policromía, con todos sus estratos, ocupará un nivel, por lo tanto habrá tantos niveles como policromías presente la talla.

Partiendo del muestreo completo, se puede establecer igualmente la localización y extensión de cada una de las policromías.

Teniendo en cuenta que cada nivel corresponde a un periodo y una fecha concreto se consigue establecer la cronología relativa de cada policromía.

Por otro lado, de la información que aparezca reflejada en documentos de época, de las características estilísticas o técnicas propias de fechas concretas, etc., se podrán establecer cronologías absolutas.

La realización de la carta permite tener una visión de conjunto bastante esclarecedora. Estableciéndose las diferentes policromías y en qué periodo se han realizado intervenciones totales o sólo parciales.

GRÁFICO 1. Tabla de correspondencia de policromías

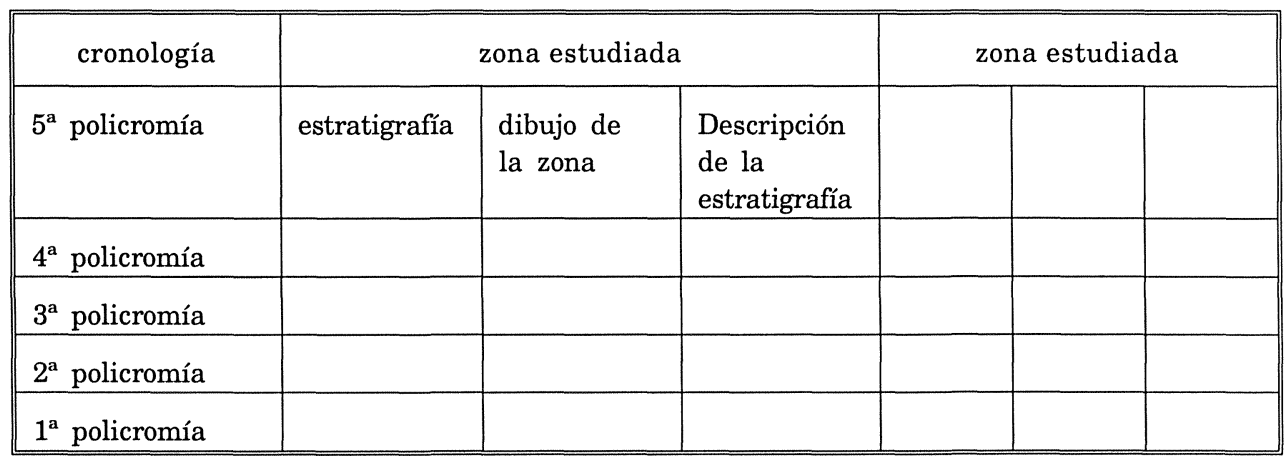


A partir de esta visión global, se pueden a veces llegar a algunas hipótesis de tipo histórico, como por ejemplo si las modificaciones han coincidido con fechas en las que se han producido cambios litúrgicos, estilísticos, etc.

También se pueden deducir situaciones económicas, ya que las tareas de policromado suponían unos gastos mayores o menores en función de la extensión de la intervención y de la calidad de los materiales empleados.

Si una pieza presenta numerosas policromías superpuestas y las subyacentes están en relativo buen estado de conservación, puede inducir a pensar que se trata de una imagen de gran devoción, que se ha ido poniendo al día periódicamente.

Desde el punto de vista técnico, es especialmente interesante la constatación del uso de los distintos materiales y técnicas cronológicamente. A partir de esta información y contando con los tratados existentes al respecto, se puede ir estableciendo una Historia de las Técnicas de la Policromía bastante fiable y científica.

Por otro lado se pueden obtener datos de interés para la Historia del Arte, en especial si se pueden comparar estudios de correspondencias de distintas piezas de una misma región. Así se conocería la actividad de ciertos talleres, qué estilos han tenido una mayor incidencia en la zona, en qué medida la región estudiada ha estado influenciada por las diferentes corrientes estilísticas, etc.

Todas estas conclusiones e hipótesis deben quedar reflejadas por escrito, siendo necesaria la colaboración de especialistas en la materia para las cuestiones históricas y estilísticas.

Presentación de resultados y reconstrucción gráfica:

Una vez finalizado el estudio y realizada la carta de correspondencias, que nos habla de las distintas policromías, de su localización y extensión, podemos proceder a la reconstrucción gráfica de cada una de ellas. Para ello, sobre un croquis de la talla, de una o varias de sus vistas, podemos realizar gráficamente réplicas de las distintas policromías que ésta posee.

Esto se puede llevar a cabo manualmente o mediante ordenador, con un programa de tratamiento de imagen, como veremos más adelante.

La reconstrucción de las diferentes policromías permite apreciar claramente la evolución histórica de la pieza, evitando la necesidad de eliminar las repolicromías, constituyendo un elemento de utilidad didáctica. 


\subsection{Criterios de intervención sobre las repolicromías:}

Como hemos visto anteriormente la ley y otros documentos internacionales, como la Carta de Venecia, el Código Deontológico de la profesión y numerosos escritos sobre criterios aceptados internacionalmente, protegen la obra de arte y sus añadidos históricos. Esta protección incluye las policromías superpuestas, o repolicromías, por lo que en la mayoría de los casos eliminarlas puede constituir un atentado contra el Patrimonio.

La decisión de eliminar una o varias policromías deberá ser meditada y justificada convenientemente, no debe hacerse nunca en función únicamente de la opinión del restaurador, sino que ha de ser tomada por una comisión de especialistas en Arte y en Restauración, creada a tal efecto. De todos modos hay que tener en cuenta que este tipo de intervenciones supone un elevado número de horas de trabajo, lo que se traduce en un coste muy alto para la restauración de la pieza, por ello es necesario, antes de llegar a esta decisión, realizar una estimación del gasto y del tiempo a emplear, para posteriormente ver si la intervención será rentable a todos los niveles, ya que es evidente que nuestro patrimonio es tan extenso y existen obras en tan mal estado que cualquier derroche de dinero y tiempo, a favor de una pieza, va en detrimento de la conservación de otras.

Sin embargo no hay por qué renunciar al conocimiento de las policromías subyacentes, por ello, la opción lógica es recurrir al estudio de correspondencias, dado que se trata de un método científico, basado en unos criterios y metodología de trabajo específicos y cuyos resultados, siempre y cuando este estudio se haga de forma correcta, son totalmente fiables.

En cualquier caso, si definitivamente se toma la decisión de levantar una policromía, se deberá encargar el trabajo a personal especializado que pueda disponer del equipamiento necesario para llevarla a cabo con las suficiente garantías de conservación y respeto para la policromía que subyace y que quedará al descubierto.

Finalmente el restaurador deberá tomar, gráfica y fotográficamente, todos los datos posibles sobre las zonas y capas a eliminar, de forma que el testimonio histórico que va a desaparecer quede debidamente documentado para posteriores estudios o consultas.

\section{Estudio del soporte}

En el caso de la escultura policromada, el estudio del soporte puede presentar alguna dificultad, dado que éste aparecerá total o parcialmente 


\section{Rosaura García Ramos, Emilio Ruiz de Arcaute Martínez}

cubierto de color. En algunos casos parte de la información se puede obtener revisando las zonas no policromadas o con lagunas parciales, sin embargo existe una gran cantidad de datos que no son directamente accesibles.

$\mathrm{Al}$ estudiar un soporte de madera y dependiendo de su complejidad, necesitamos saber:

- El tipo de material utilizado (tipo de madera).

- El número de piezas empleadas en su construcción.

- El sistema de corte y desbastado (herramientas utilizadas).

- La dirección del corte de las piezas.

- El tipo de ensamblajes («uniones vivas», machihembrados, con espigas, etc.).

- Sistemas de sujeción o refuerzo.

- La existencia de elementos añadidos.

- La existencia de elementos en su interior.

- La existencia de defectos de la madera.

- La existencia de ataques biológicos en el soporte.

- Las posibles transformaciones, su localización y cuál es su extensión.

- Etc.

Todavía hoy encontramos numerosos ejemplos de intervenciones en los que para obtener estas informaciones se desmonta y secciona la escultura, lo que inevitablemente acarrea daños a la misma. Hay que tener en cuenta que en la mayor parte de los casos los datos obtenidos no justifican los daños causados, por mucho cuidado que se haya puesto en la realización de estas operaciones.

Teniendo en cuenta la importancia dada al valor de la pieza, al igual que en el caso de las policromías las intervenciones sobre el soporte han de ser lo más respetuosas con su integridad y para ello es necesario acudir a técnicas de estudio no destructivas o que lo sean mínimamente.

\subsection{Los rallos $X$.}

Tradicionalmente la técnica de estudio más utilizada ha sido y sigue siendo la radiografía convencional. Este examen debe ser realizado con un buen equipo y por personal especializado.Es necesario conocer las necesidades de exposición (intensidad y tiempo de radiación) de los diferentes materiales y volúmenes utilizando material de calidad y placas de alta resolución para mejorar la definición de la imagen. Por comodidad, en el caso de imágenes de cierto tamaño, es con- 


\section{La escultura policromada. Criterios de intervención.......}

veniente utilizar película en rollo, que permite reducir el número de empalmes.

Se han de realizar al menos dos tomas radiográficas de la escultura, una frontal y otra lateral, para poder determinar mejor la situación, dirección y ángulo de los diferentes elementos. Con frecuencia, dada la diferencia de volumen de las distintas zonas de la talla, se producen distintos grados de densidad en la placa, que puede obligar a repetir las tomas con diferente exposición para mejorar la imagen.

Foto 4. Busto-relicario del S.XVI. Museo de Arte Sacro de Vitoria

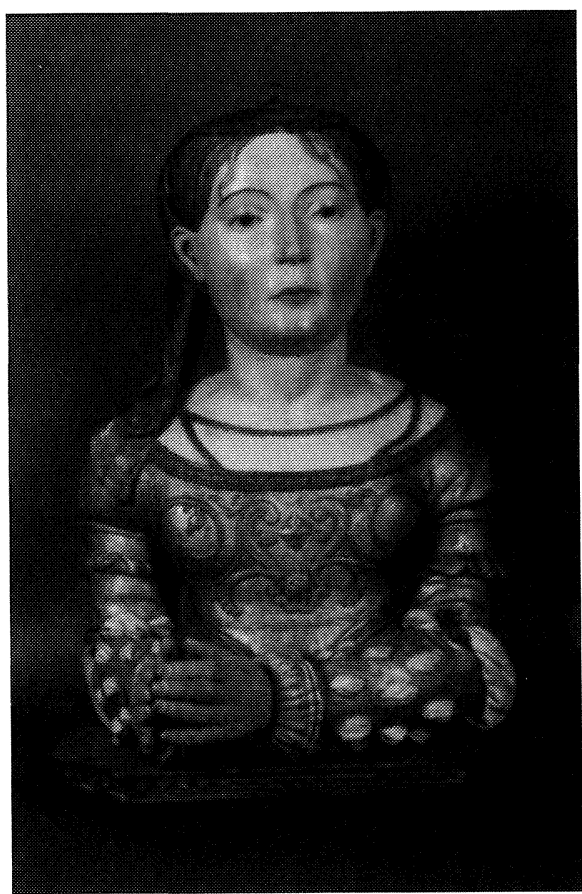

Los R.X. permiten localizar elementos metálicos, como clavos, tornillos, bisagras, etc. También suelen mostrar zonas ahuecadas, elementos añadidos, sistemas de ensamblaje como espigas u otros la localización de elementos en el interior de la imagen, ciertas transformaciones, etc.

En algunas ocasiones, sin embargo, por la acumulación de distintos materiales, la presencia de elementos metálicos o capas de recubrimiento a base de plomo, la información puede aparecer confusa y enmascarada, por lo que se hace necesario afinar en el estudio radiográfico o cambiar de técnica de análisis. 


\section{Rosaura García Ramos, Emilio Ruiz de Arcaute Martínez}

664

Foto 5. Radiografía frontal del busto

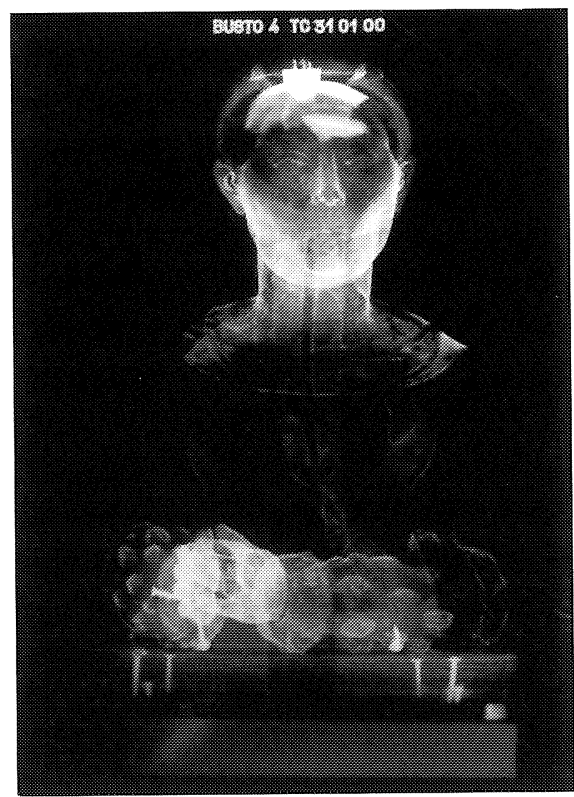

Foto 6. Radiografía lateral del busto

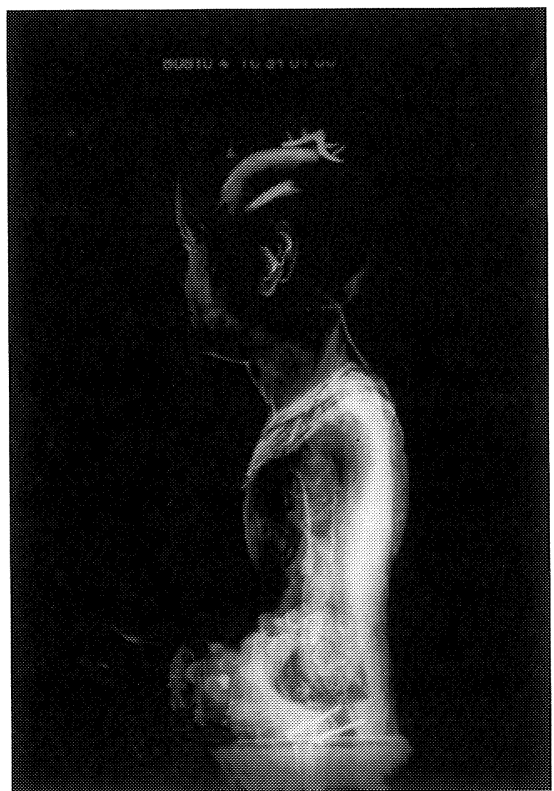




\subsection{La tomografía computerizada}

De forma esporádica, en especial por su elevado coste, se aplica la tomografía al estudio de la escultura. Esta técnica permite obtener imágenes de secciones de una pieza mediante la emisión de R.X.

En síntesis, consiste en una fuente de emisión de R.X. que pasa por un colimador, que produce un fino haz que atraviesa la pieza. Esta va girando y así se obtienen diversas proyecciones que son captadas por un pluvidetector que trasmite las señales recibidas a un ordenador encargado de restituir la imagen del corte. Los equipos industriales permiten obtener distintos grados de resolución y medir las dimensiones, espesores y densidades.

De una misma pieza es recomendable realizar varios cortes a distintas alturas, para comprobar las diferencias existentes en estos puntos.

Foto 7. Realización de tomografía de la imagen de Nuestra Señora de Escolumbe, en la Empresa TOMO ADOUR, Pau (Francia)

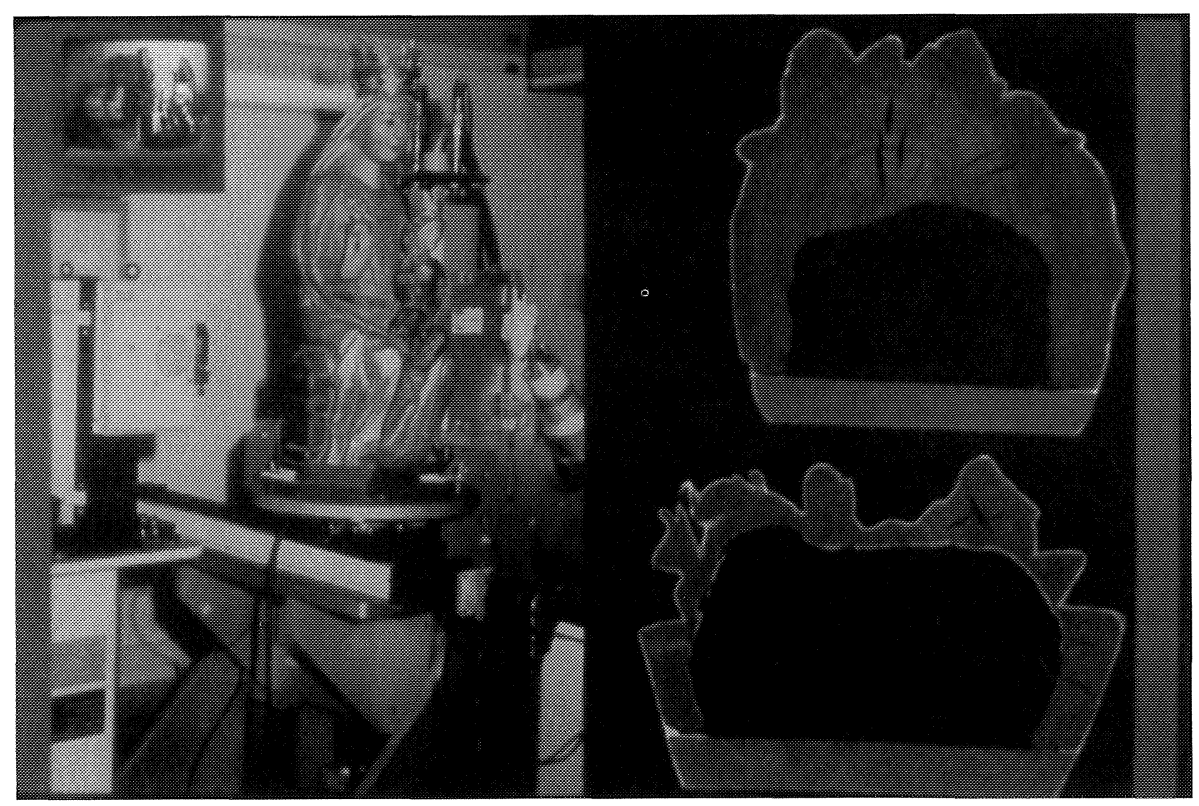


La tomografía permite determinar el tipo de madera utilizado, el tipo de corte de las mismas, su estado de conservación, el número de piezas que componen la escultura, su localización, dimensiones y colocación, los sistemas de ensamblaje, la existencia de huecos y defectos de ensamblado, la presencia de elementos en su interior, las transformaciones sufridas por la talla, etc.

En algunos casos, si se cuenta con imágenes de alta resolución de cortes que permiten apreciar claramente los anillos de crecimiento de la madera, podemos intentar un estudio dendrocronológico para datar la pieza.

Se trata de una técnica que no debe estar pensada para competir con la radiografía tradicional, sino más bien para completar o aclarar los datos ofrecidos por ella.

Foto 8. Corte tomográfico del busto-relicario de Santa Balbina. Museo de Arte Sacro de Vitoria. Se observa el $\mathrm{n}^{\circ}$ de piezas, la dirección de las mismas, los anillos, etc.

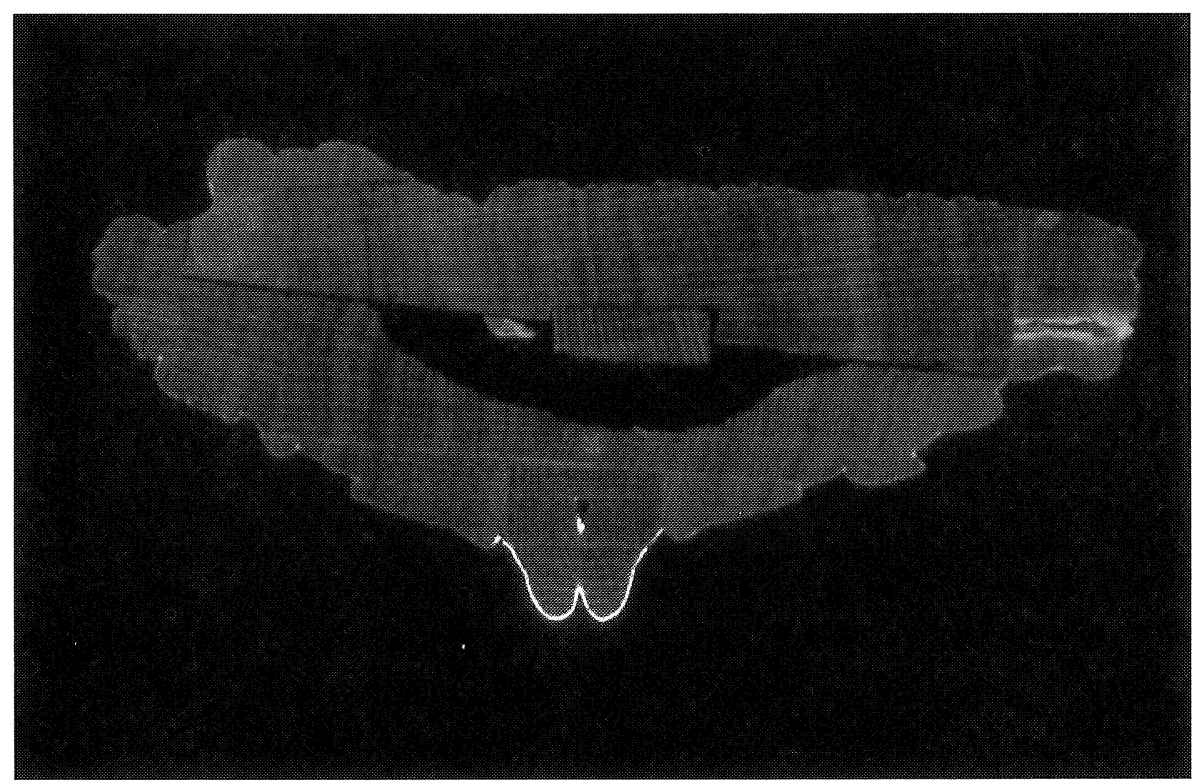




\section{La escultura policromada. Criterios de intervención......}

\subsection{La endoscopia}

Si contamos con vías de acceso naturales al interior de la talla, podemos además completar el estudio de la misma con el empleo de la endoscopia.

Esta técnica permite la observación de cavidades, comprobar la existencia de elementos en su interior, identificar los materiales, etc. y está especialmente indicada para el estudio de relicarios y esculturas que presentan escritos en su interior.

La combinación de este tipo de técnicas permite en la mayoría de los casos evitar mutilaciones y desmembramientos, obteniendo una información muy completa, como en el caso del estudio del busto relicario de Santa Balbina del Museo de Arte Sacro de Vitoria.

A partir de este estudio pudimos establecer: que el busto estaba compuesto de 14 piezas de roble de distinto tamaño, sin contar con las de la peana; que salvo dos espigas de $50 \times 11 \mathrm{~mm}$, que sujetaban los bloques principales, el resto de las uniones eran «vivas»; que la talla se realizó a partir de dos tablones similares de aproximadamente

Foto 9. Realización de una inspección endoscópica del busto-relicario de Santa Balbina. Museo de Arte Sacro de Vitoria (con un video-endoscopio Olympus IV6C5-20,35).

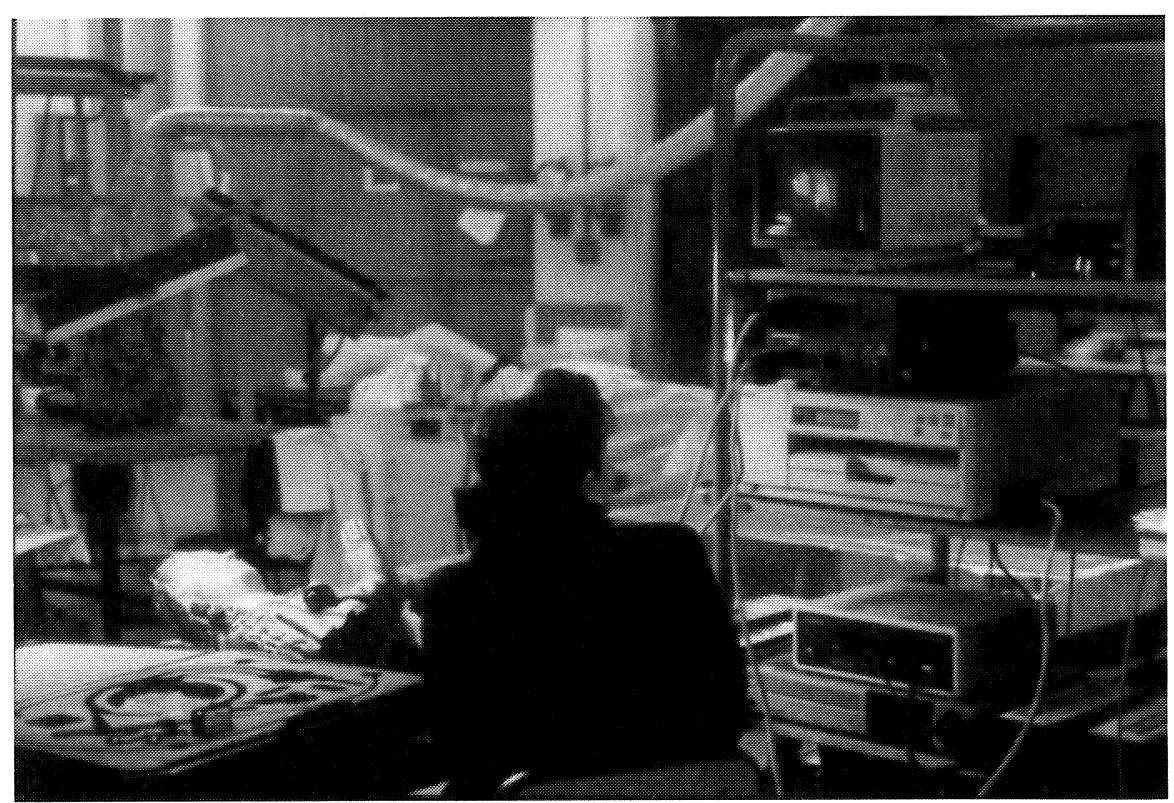


$31 \times 58 \times 7 \mathrm{~cm}$, a los que se habían encolado otras piezas; que los tablones habían sido cortados en sentido radial y que cuando se utilizaron estaban ya secos; que la talla de la imagen se había terminado tras ahuecar el interior de las piezas principales e introducir las reliquias; que la colocación de alguno de los huesos impidió unir perfectamente las piezas centrales, recubriéndose los defectos con chuletas de madera, preparación y policromía; que los huesos, fragmentos de distintas partes, se encontraban distribuidos entre la cabeza y el tronco del relicario, envueltos en telas de lino y seda azul, bordadas con lentejuelas y atadas con una cinta de hilos verdes y dorados.

Esta información no sólo nos aporta datos sobre la construcción de una pieza concreta, sino que nos permite conocer la técnica de realización de este tipo de bustos relicarios. Podemos así compararlas con los otros cuatro ejemplos conservados en el museo de Vitoria, con los dos que se encuentran en el Museo de los Caminos de Astorga y con el de la Sacra capilla de Ubeda y observar suficientes coincidencias técnicas como para defender la idea de un origen común. Algo que también parece desprenderse de los estudios estilísticos e históricos.

Foto 10. Detalles radiográficos del busto-relicario de Santa Balbina. Museo de Arte Sacro de Vitoria

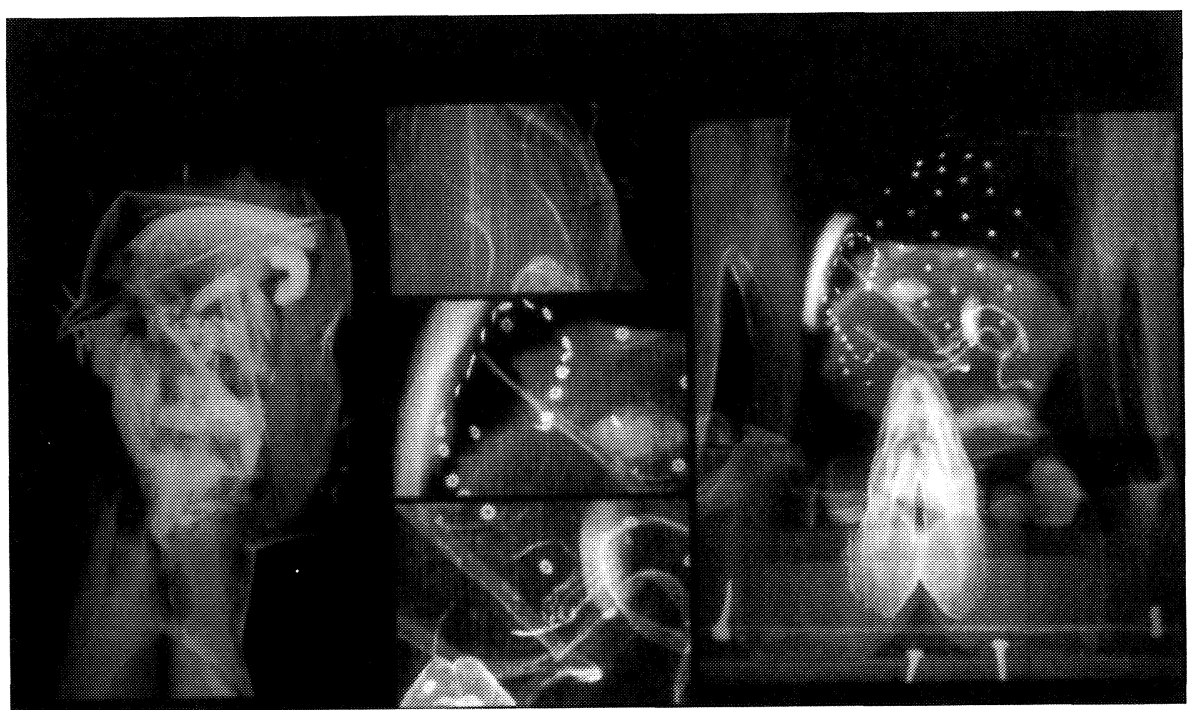


Foto 11. Combinación de imágenes radiográficas y endoscopia del mismo busto

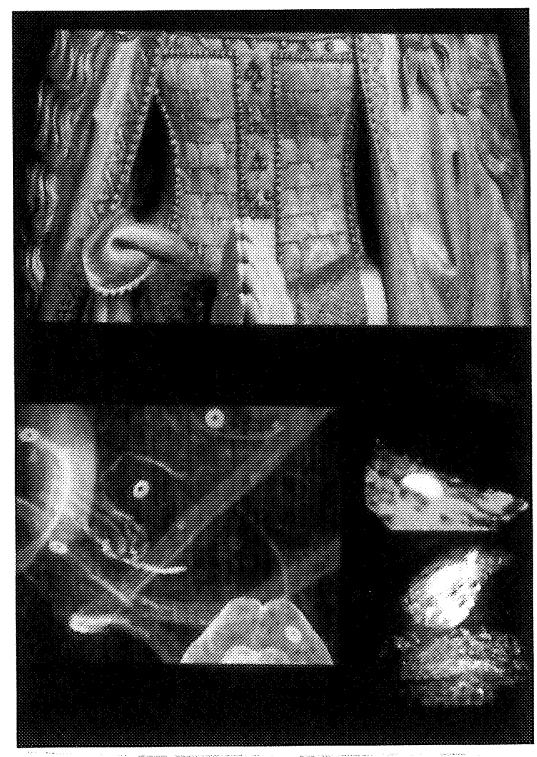

Foto 12. Combinación de imágenes tomográficas y radiografía del mismo busto

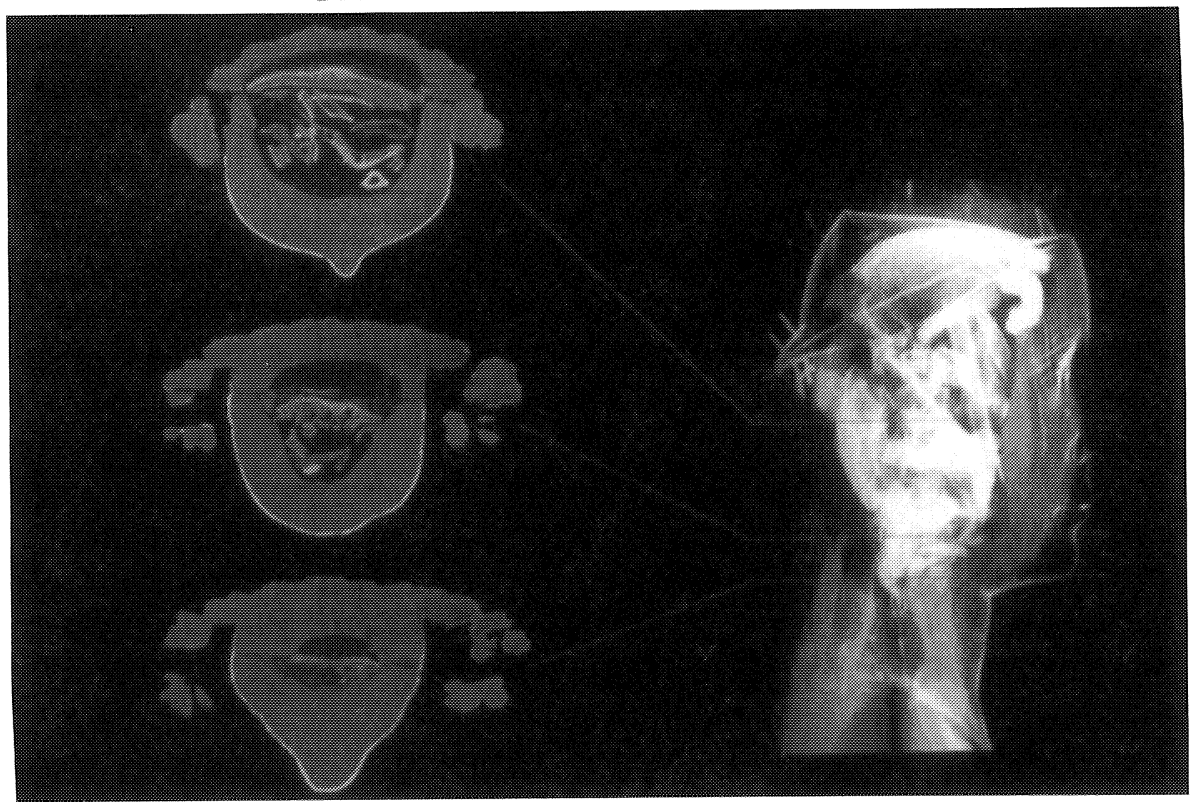




\section{Las nuevas tecnologías aplicadas a la escultura policromada}

Las crecientes posibilidades de las nuevas tecnologías han llamado la atención en muchos campos profesionales. En los últimos años hemos visto proliferar propuestas de aplicación al campo de la arquitectura, la arqueología, etc., incluso a la restauración. Pero es necesario ser conscientes de las posibilidades reales y de las limitaciones que presenta su utilización en un campo tan concreto como el de la escultura policromada.

Una de las aplicaciones más interesantes y en la que nos vamos a centrar, es la reconstrucción virtual de fases históricas.

Como se ha dicho, por motivos deontológicos, en el estudio de policromías optamos por respetar las distintas intervenciones históricas, procurando trabajar con técnicas mínimamente destructivas, aceptando las dificultades y limitaciones que ello supone.

Esta forma de actuar tiene como consecuencia la obtención de una información limitada, porque no se suelen eliminar las policromías ni se abren grandes ventanas y nos obliga a dedicar más tiempo de trabajo al cruzado de información, a una selección mayor de puntos de estudio, a la utilización de más medios y técnicas auxiliares, como los $\mathrm{RX}$, la espectrografía de infrarojos o los ultravioletas, etc.

Este tipo de estudios presenta gran complejidad y muchos meses de estudio. Por ello los costes son también elevados, aunque por lo general la información obtenida puede compensar tanto derroche técnico y humano.

Para rentabilizar adecuadamente tanto esfuerzo, que por lo general está financiado por recursos públicos, estamos obligados moralmente a divulgar los resultados no sólo en círculos especializados. Y es en este punto donde las nuevas tecnologías tienen una utilidad especial, permiten democratizar el acceso a la información, ya que, mediante el tratamiento virtual de la imagen, podemos mostrar de forma clara y comprensible las diferentes fases históricas de las esculturas policromadas.

\subsection{Reconstruccion en 2-D}

Las primeras reconstrucciones virtuales que realizamos, a principios de los «90», eran de baja resolución, ya que no contábamos con equipos con la suficiente potencia y memoria. Posteriormente, y con equipos más modernos, hemos podido realizar trabajos de mayor calidad.

El proceso de trabajo, es sencillo. Se parte de un escaneado de alta resolución de imágenes fotográficas. Estas imágenes son posteriormente 


\section{La escultura policromada. Criterios de intervención......}

Foto 13. Reconstrucción virtual de las seis policromías sucesivas de la imagen de Santiago del Pórtico Este de la Iglesia de San Pedro de Vitoria. Las dos primeras fases no se han reconstruido por completo, ya que carecemos de información sobre los motivos decorativos que debían llevar

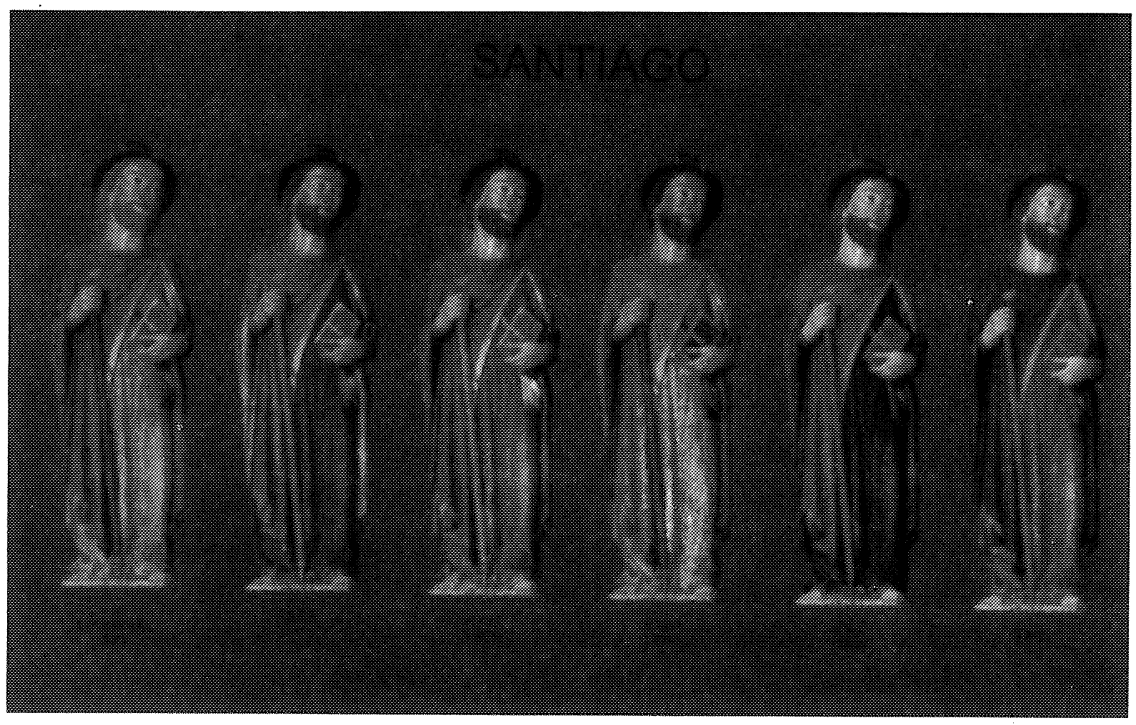

Foto 14. Reconstrucción virtual de las tres policromías sucesivas (S.XIV, XV y XVI) de una cabeza de piedra policromada de la Catedral de Santa María de Vitoria. En el ángulo inferior derecho aparece la pieza tal y como se encontraba durante el proceso de estudio

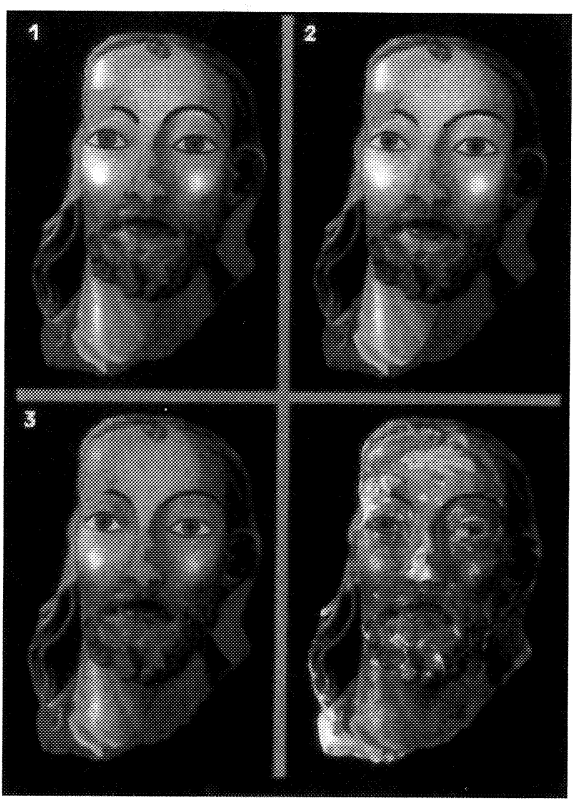


sometidas a transformaciones mediante programas de retoque fotográfico (nosotros empleamos el programa Photoshop 5 ()), para pasar finalmente a ser filmadas en película fotográfica, a ser impresas en papel, etc.

El mayor problema consiste en trasladar toda la información obtenida mediante los estudios de correspondencia de policromía, que tienen que estar realizados con anterioridad.

\subsection{Imágenes en 3-D}

En la actualidad, dentro de un proyecto de $\mathrm{I}+\mathrm{D}$, estamos realizando ensayos para obtener reconstrucciones virtuales de esculturas policromadas en tres dimensiones. En este proyecto, que está relacionado con el Plan Director de la Catedral de Santa María de Vitoria, también participa el Equipo de Documentación Arquitectónica de la Universidad del País Vasco, la empresa EUVE de Vitoria y TEKNOARTE, empresa dedicada a la edición de productos multimedia.

Esta solución presenta más dificultades técnicas que la realización de imágenes en $2 \mathrm{D}$, pero permite realizar presentaciones en movimiento, animaciones o multimedia.

Para elaborar imágenes en 3-D tenemos que trabajar con otras técnicas y otros programas. Se necesita partir de un sólido, un cuerpo o una figura en tres dimensiones, a la que posteriormente se le aplicaran texturas para reproducir las calidades y colores de los materiales. Por el momento estamos en las fases iniciales del proyecto y se están realizando los primeros ensayos de reconstrucciones. También será necesario seleccionar los mejores sistemas para aplicación de texturas y colores, ya que los programas habituales sólo permiten la aplicación de una textura a cada sólido.

\subsection{Otras utilidades}

Comunmente se viene utilizando este tipo de tecnologías para la reconstrucción de mosaicos de radiografías o reflectografías. Una utilidad sencilla y que no precisa de mucha manipulación ni de grandes equipos.

Las nuevas tecnologías de tratamiento de imagen también pueden ser utilizadas para la reconstrucción virtual de motivos decorativos de las policromías. En nuestro caso, estamos realizando este tipo de 
trabajos a partir de fotografías de fragmentos. Esto nos ha permitido recuperar por ejemplo motivos de policromías del XVIII de la Portada de San Pedro de Vitoria y Brocados aplicados de los retablos Mayores de la Iglesia de San Vicente de Arana (Alava) y de la Iglesia Parroquial de la Puebla de Arganzón (Condado de Treviño).

Foto 15. Reconstrucción al ordenador, a partir de fragmentos, del motivo de «brocado aplicado» del Retablo Mayor de la Iglesia de San Vicente de Arana.

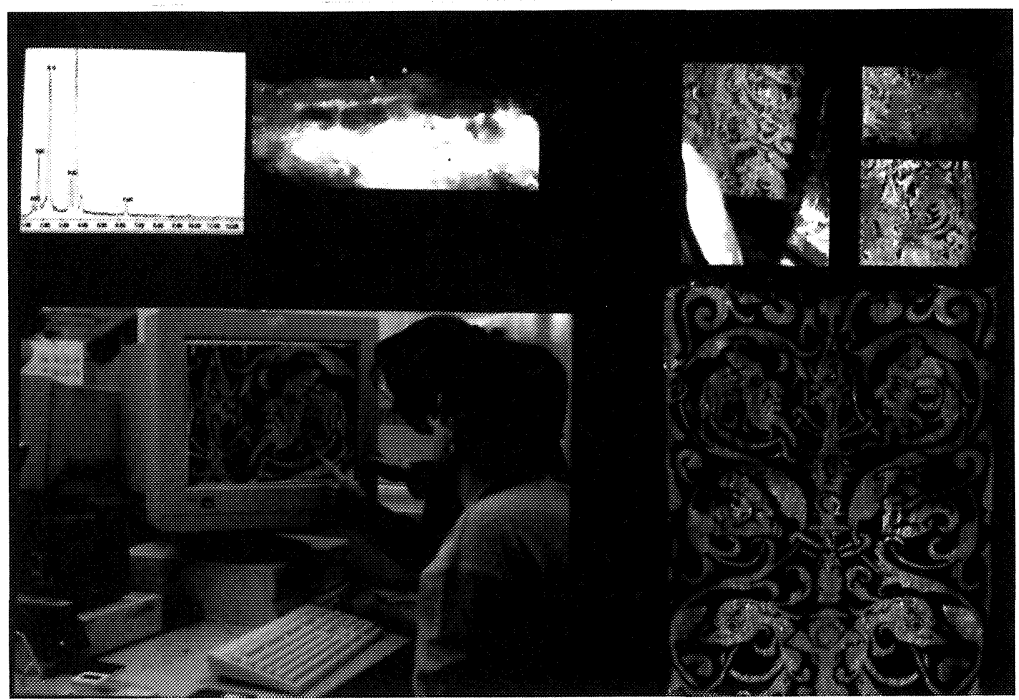

Otras utilidades más comunes son la elaboración de esquemas, gráficos y otro material didáctico.

La reconstrucción mediante el ordenador de las policromías supone, frente a otras técnicas de representación gráficas ciertas mejoras como la obtención de una imagen realista de alta calidad, fácilmente comprensible, sin tener que destruir las policromías estudiadas; permite el acceso de la información científica a todo el mundo; al ser una imagen digital, una vez creada se puede utilizar de muy diferentes maneras: incluirla en documentos o publicaciones, copiarla, transformarla, unirla a otras imágenes y reutilizarla en cuantos montajes se quiera; se puede utilizar para presentaciones científicas, para la elaboración de material didáctico en la formación de especialistas, para la divulgación cultural, para la promoción turística, etc.

Sin embargo también presenta algunos inconvenientes que hay que tener en cuenta como que requiere contar con el equipo material y los programas necesarios, que hay que contar con especialistas que 
conozcan el tratamiento de imagen y los estudios de correspondencia de policromía, que supone muchas horas de trabajo en la fase de retoque y eso tiene un coste elevado, que no siempre permite mostrar detalles con la suficiente claridad; además, el hecho de que la imagen parezca real tiene sus riesgos, ya que se puede engañar fácilmente presentando una reconstrucción falsa.

Evidentemente, no en todos los casos está justificada su utilización, pero pensamos que en aquellos estudios cuya relevancia científica o cuya importancia artística lo merezcan, puede ser una de las mejores maneras de presentar los resultados.

\subsection{Criterios de utilización de las nuevas tecnologías}

Pero hay que recalcar que en el caso del tratamiento de imagen aplicado al campo de la restauración se están produciendo grandes errores. Con frecuencia encontramos ejemplos de reconstrucciones virtuales que más que presentar el resultado de un estudio científico muestran las habilidades y las conjeturas de su realizador. Nada más sencillo, nada más vistoso que la transformación de la apariencia de una imagen por medio del ordenador.

Por ello tenemos que tener mucho cuidado y ser especialmente escrupulosos en este campo, ya que si no podemos caer en «los efectos especiales» o en la mera falsificación.

Con esta intención hemos establecido una serie de criterios para la correcta utilización de estas técnicas en el campo del Patrimonio Cultural. Toda transformación virtual de una imagen ha de cumplir una serie de requisitos deontológicos:

- En primer lugar la transformación virtual de la imagen ha de estar debidamente justificada. Debe ser necesaria para la comprensión de la evolución de la obra y aportar mejoras frente a otras técnicas de representación.

- Debe ser la consecuencia de un previo estudio científico-técnico y estar basado en datos objetivos, para no crear falsos.

- Si se presentan hipótesis, éstas deben estar adecuadamente identificadas como tales.

- La transmisión de la información histórica ha de ser clara. No debe dar lugar a confusiones o interpretaciones erróneas.

- La imagen virtual debe ir acompañada de la imagen real de la que se parta, para que el espectador pueda distinguir claramente entre realidad y reconstrucción. 
La escultura policromada. Criterios de intervención......

- La reconstrucción virtual al ordenador ha de ser realizada por un especialista que conozca y comprenda perfectamente la información que se desprende del estudio de correspondencia de policromías. Debe conocer las características de los materiales y las técnicas empleadas en la realización de la obra.

\section{Conclusión}

En resumen, es necesario que los criterios de los conservadoresrestauradores de escultura policromada velen por la permanencia de este patrimonio y por su transmisión futura en las mejores condiciones posibles. Desde este punto de vista se debe recapacitar sobre la realización de determinados tratamientos, desafortunadamente irreversibles, que causan verdaderos estragos en las obras y que, en ocasiones, sólo sirven para dar satisfacción al «restaurador» que los aplica o a especialistas en otras disciplinas que se creen en el derecho de supeditar a sus intereses los tratamientos de conservación que se deben aplicar a la obra, sin tener en cuenta el bien de la misma, como defienden los criterios internacionalmente aceptados y nuestra legislación.

Hablando en términos médicos, el restaurador debe velar siempre por el bien del paciente y por su integridad, debe ser estrictamente exigente consigo mismo y con el código deontológico de su profesión, debe huir siempre de tratamientos drásticos, a no ser que sean absolutamente necesarios, debe utilizar los métodos menos destructivos o agresivos, debe servirse de las nuevas tecnologías para el estudio y diagnóstico de los males que afectan al paciente y para la aplicación de los tratamientos, sin llegar nunca a ponerse a disposición de éstas, debe estar al día de las últimas investigaciones $\mathrm{y}$, sobre todo, debe evitar que otro tipo de intereses, personales o ajenos, hagan que su trabajo pueda ser calificado como «desgraciada intervención». Además hoy, como hemos dicho, debemos poner un especial acento en la prevención, en la llamada «conservación preventiva», para evitar tener que recurrir a tratamientos que siempre suponen efectos secundarios.

Se trata de una complicada labor de concienciación propia y ajena, ya que son muchas las presiones y los condicionantes, en numerosas ocasiones económicos, a los que enfrentarse a la hora de decidir sobre lo mejor para la obra. 


\section{Rosaura García Ramos, Emilio Ruiz de Arcaute Martínez}

\section{Bibliografía}

Prier-Dieteren, C. La Restauration en Belgique de 1830 à nos Jours (1991). Liège.

Philippot, P. «La Restauration des Sculptures Polychromes» (1970) en Studies in Conservation, $\mathrm{n}^{\circ}$ 15. pp. 248-252.

Philippot, P. «Problèmes esthétiques, et archélogiques de conservation des sculptures polichromes» (1979) en Preprints of the Contributions to the New York Conference on "Conservation of Stone and Wooden Objects", Section Wood. N.Y. pp.59 62.

Ballestrem, A. "Cleaning of Polichromes Sculptures", (1970) en Preprints of the Contributions to the New York Conference on "Conservation of Stone and Wooden Objects", Section Wood. N.Y. pp 69-73.

TAubert, J. «The Conservation of Wood» (1970) en Preprints to the Contribution to the New York Conference on "Conservation of Stone and Wooden Objects", Section Wood. N.Y. pp. 81-85.

Garcí Ramos, R. «El Examen Material de la Obra de Arte. La Correspondencia de Policromias» (1990) en Master de Museología. UPV. (Facultad de Geografía e Historia). Vitoria. pp. 211-226.

Garcfa Ramos, R. «Examen Material de la Obra de Arte. La Correspondencia de Policromias» (1995) en boletín informativo. Instituto Andaluz del Patrimonio Histórico. Sevilla. pp. 52-57.

Garcta Ramos, R. y Rutz de ArCaute, E. "Aproximación al Brocado Aplicado en España. Desarrollo y Extensión" (1996) en Comunicaciones del Congreso del Grupo Español del IIC. Castellón. pp. 747-756.

García Ramos, R. y Ruiz de Arcaute, E. "La Técnica de Correspondencia de Policromías y el Tratamiento de Imágenes por Ordenador en Escultrua Policromada» (1996) en Comunicaciones del Congreso del Grupo Español del IIC. Castellón. pp. 757-762.

García Ramos, R. y Ruizde Arcaute, E. «Estudio de la Evolución Histórica de la Policromía de una Talla Gótica. Aplicación de la Técnica de Correspondencia de Policromías» (1996) en Comunicaciones de las Jornadas de Arte Vasco. »Revisión del Arte Medieval en Euskal Herria». San Sebastián. pp. 365- 373.

Garcí Ramos, R. y Rutz de ArCaute, E. "Aportaciones al Estudio de "Corespondencia de Policromías". Criterios y Técnicas» (1997) en KERMES, n² 29. Florencia. pp. VII-XII.

GARCIARAMOS,R. «Problemas de Coordinación Técnica en Exposiciones Temporales» (1998) en ADCR, Boletim n ${ }^{\circ}$ 8/9 de la Associaçao para o Desenvolvimento da Conservaçao e Restauraçao. Lisboa. pp. 24-27.

García Ramos, R. y Ruizde Arcaute, E. "Técnicas de Estudio de la Escultura Policromada» (1999) en $9^{\circ}$ Congreso Nacional END. Asociación Española de Ensayos no Destructivos. Vitoria. pp. 203-211.

GarctaRamos,R. y RuizdeArCaUte, E. «The conservation and restoration of the polychrome sculpture in Alava. The main altarpiece of San Vicente de Arana and the Bustreliquaries of the Church of San Miguel de Vitoria" (1999) en Polychrome Skulptur in Europa. Technologie-Konservierung- Restaurierung. Dresde. pp. 84-89.

Garcia Ramos, R. y Ruiz de Arcaute, E. "Los Bustos Relicarios de las Once Mil Vírgenes. Claves para su Estudio" (2000) en AKOBE n 1 Boletín de la Asociación de Conservadores-Restauradores de Bienes Culturales de Alava. Vitoria. 